\title{
INVESTIGATION OF HAPPINESS DETERMINANTS USING THE OXFORD QUESTIONNAIRE IN STUDENTS OF THE UNIVERSIDAD FRANCISCO JOSÉ DE CALDAS
}

\section{ALBERTO ACOSTA LÓPEZ, OCTAVIO JOSÉ SALCEDO PARRA \& ROBERTO MANUEL POVEDA CHAVES}

Faculty of Engineering, Universidad Distrital Francisco José de Caldas, Bogotá, Colombia

Objective: The purpose of this paper is to investigate the relationship between the model of 41 questions: personal and those related to the Oxford questionnaire, among the students of the Engineering Faculty of the District Universidad F. José de Caldas Bogotá, Colombia 2019.

Materials and methods: in this descriptive study, it was conducted with 162 students of the Engineering Faculty of the District University F. José de Caldas Bogotá, selected by stratified random sampling. For data collection the demographic survey and the Oxford happiness survey, the OHI inventory (Hills \& Argyle 2002),) were used. Data were analyzed using descriptive statistics (percentage, mean and standard deviation) and inferential statistics (Pearson's moment-product correlation coefficient and multiple regression analysis). The statistical software SPSS V.21 (Nie and Hadlei 1970) was used, software for data analysis.

The results obtained indicate that: the transfer time of less than one hour from home to the University, the fact of being a believer of a religion, and an academic average greater than 3.5, generates a high level of happiness in students On the other hand, gender (male, female) and the economic statement were not significant in the determination of happiness. Similarly, based on the results obtained in this study, the inventory of Oxford OHI (Hills \& Argyle 2002), could be endorsed as a valid and reliable means of measurement, so it can be used to assess happiness in university students.

KEYWORDS: Well-being, Happiness, Questionnaire, Regression \& Reliability
\end{abstract}

Received: Nov 07, 2020; Accepted: Nov 27, 2020; Published: Dec 05, 2020; Paper Id.: IJMPERDDEC20209

\section{INTRODUCTION}

The importance of measuring happiness is recommended and determined to date, by academics, managers and professionals, committed to restoring people's non-monetary welfare; scientific research on this subject has increased in recent years, especially when dealing with university students, happiness becomes vital, because every human being desires to be happy; to the point of becoming the most explored habit. Greek philosophers such as: Socrates, Plato and Aristotle, had an eudaimonic vision of happiness, they considered that being happy meant leading a virtuous life that was only achieved through wisdom (Aristotle, 1985). Epicurus, on the other hand, wonders what it is that moves humans to work, because happiness will consist in achieving it, and that thing is pleasure. 
Since not everyone was called to live a life in virtue (Leahey, 2011). Hence two conceptions of happiness are identified, one conceived as eudaimonia that comes from wisdom, and another hedonic, focused on the acquisition of goods and therefore, the satisfaction of needs. According to this vision, happiness is acquired when the desired good is obtained (Alarcón, 2009). The new interest in the study of happiness uses the scientific approach based on the measurement, the elaboration of theories, the approach and the corroboration of hypotheses and the reformulation of theories. Start the measurement Ed Diener et al. (1985) building the scale of satisfaction with life that has as a particular characteristic having several items that allow addressing cognitive aspects linked to subjective well-being. The scale has been tested in various cultural contexts and countries: USA (Diener et al., 1985), Canada (Blais, Vallerand, Pelletier \& Briere, 1989), China (Shao \& Diener, 1992, cited in Pavot \& Diener, 1993 ), Russia (Balatsky \& Diener, 1993), Korea (Suh, 1993, cited in Pavot \& Diener, 1993), Brazil (Gouveia, Milfont, Nunes da Fonseca \& Peçanha, 2009), Denmark (Clench-Aas, Nes, Dalgard \& Aarø, 2011), among others.

The purpose of this study is to adapt and validate the scale of OHI (Hills \& Argyle 2002), in the students of the Faculty of Engineering, of the Francisco José de Caldas District University located in the city of Bogotá,-Colombia. In order to inform its levels of reliability and validity indications of the construct; this allows to make available to the researchers of the area a scale with solid psychometric properties and duly replicated in various studies. It will also provide indications of the levels of life satisfaction reported by a sample of Colombian university students.

The study has been structured as follows: initially, the method, its participants, the design and the tool used to support the estimation are described. Subsequently, the results of the evaluation and discussion are described. Similarly: the relevance of the variables chosen as determinants of happiness is explained, indicating and analyzing the results found in this study, pointing out the differences found with respect to the available literature.

\section{METHODOLOGY}

The present study, we used the demographic survey, and the Oxford happiness survey the OHI inventory (Hills \& Argyle 2002). Study based on a psycho-metric property test, developed at the University of Oxford on the happiness of university students. The happiness index was taken as a dependent variable and the statistical software SPSS V.21 (Nie and Hadlei 1970) was used, a program for data analysis, with which the impact caused by each variable can be appreciated: level of confidence, hypothesis contrast, correlation, reliability (Cronbach's alpha), with respect to the dependent variable (happiness). Thirteen independent variables of quantitative and dichotomous type were added to the survey prepared by Oxford, thus including academic, social, economic, cultural factors, with the purpose of analyzing the objective or particular characteristics of each person on the level of happiness.

The independent variables to take into account in the binary logistic regression on the level of happiness are the following:

- Age

- Gender

- Semester

- Economic stratum

- Marital status

- Work

- Academic average 
- Believer

- Type of house that lives

- Who pays for their studies

- Level of your income with respect to monthly expenses

- Average daily time, cell phone use

- Transfer time, House-University

The collection (sample of data), is composed of 162 students, belonging to the Faculty of Engineering of the Universidad Distrital Francisco Jose de Caldas in Bogotá, that are part of the curricular projects of; Electronics, Systems and Industrial Engineer. On the other hand, $90 \%$ belong to the male gender and the remaining $10 \%$ to the female gender, the data were taken between September 11 and October 26, 2019. In a voluntary, anonymous and sincere way the responses of the students were verified to avoid syntax errors or multiple responses in the survey.

As already mentioned, the Happiness Index was taken as a dependent variable. To determine the students' happiness scale, the SWLS (Satisfaction with Life Scale) scale was used. It is important to mention that the fundamental purpose of the SWLS scale focuses on calculating the overall satisfaction of people, but does not determine specific aspects such as: gender, academic average and / or economic statement. The scale consists of 5 Likert statements with a rating of 1 to 5 , where 1 is taken as low happiness and 5 is taken as high happiness (Diener et al., 1985).

On the other hand, it is pointed out that, a measurement of "1" denotes that the person totally disagrees, " 2 " indicates that they more or less disagree, " 3 " neither agrees nor disagrees, " 4 " indicates that they more or less agree and " 5 " totally agrees. This is because the most common Likert scale contains five categories (Aguayo. 2017).

\subsection{Dichotomous variables}

- Gender (male / female)

- Marital status (single / other)

- He is a believer (yes / no)

- Work (yes / no)

\subsection{Quantitative Variables}

- Age (20 or less / more than 20

- Semester (1 to 5 / 6 to 10 ),

- Economic stratum (1 and $2 / 3$ or more)

- Level of your income with respect to your monthly expenses (Low / Enough)

- Academic average (Less than or equal to 3.5 / Higher than 3.5)

- Type of house (Rent / Own)

- Who pays for their studies (Family or other / yourself)

- Average daily time of cell phone use (0 - $120 \mathrm{~min} /$ more than $120 \mathrm{~min})$

- Transfer time from the University - House (0 - $60 \mathrm{~min} /$ more than $60 \mathrm{~min})$

\section{RESULTS}

The following table shows the results obtained for the Cronbach Alpha index applied to the 29 questions of the Oxford 
questionnaire. The homogeneity index (I.H) and the corrected homogeneity index (I.H.C).

Table 1: Index: Cronbach's Alpha, I.H and I.H.C

\begin{tabular}{|c|c|c|c|}
\hline Item & Alpha & I.H & I.H.C \\
\hline 1 & 0.906574 & 0.327444 & 0.259475 \\
\hline 2 & 0.907173 & 0.239923 & 0.180142 \\
\hline 3 & 0.898336 & 0.724235 & 0.689671 \\
\hline 4 & 0.903191 & 0.476160 & 0.423923 \\
\hline 5 & 0.903226 & 0.476402 & 0.422938 \\
\hline 6 & 0.898767 & 0.697929 & 0.658792 \\
\hline 7 & 0.902487 & 0.513170 & 0.464738 \\
\hline 8 & 0.901762 & 0.555290 & 0.512728 \\
\hline 9 & 0.898740 & 0.699948 & 0.661347 \\
\hline 10 & 0.899371 & 0.669704 & 0.627665 \\
\hline 11 & 0.901752 & 0.554939 & 0.511378 \\
\hline 12 & 0.900743 & 0.605609 & 0.560161 \\
\hline 13 & 0.902298 & 0.535670 & 0.479085 \\
\hline 14 & 0.904821 & 0.416066 & 0.351810 \\
\hline 15 & 0.898363 & 0.741024 & 0.711436 \\
\hline 16 & 0.903933 & 0.416734 & 0.372532 \\
\hline 17 & 0.900424 & 0.633031 & 0.595687 \\
\hline 18 & 0.901325 & 0.576637 & 0.531259 \\
\hline 19 & 0.900843 & 0.600806 & 0.555434 \\
\hline 20 & 0.903363 & 0.462992 & 0.412314 \\
\hline 21 & 0.899877 & 0.668661 & 0.634995 \\
\hline 22 & 0.907611 & 0.228281 & 0.165574 \\
\hline 23 & 0.902653 & 0.515346 & 0.459145 \\
\hline 24 & 0.909203 & 0.191525 & 0.119644 \\
\hline 25 & 0.903115 & 0.480109 & 0.428251 \\
\hline 26 & 0.900318 & 0.656279 & 0.624386 \\
\hline 27 & 0.902791 & 0.494232 & 0.447337 \\
\hline 28 & 0.901967 & 0.545689 & 0.493560 \\
\hline 29 & 0.901117 & 0.591737 & 0.537842 \\
\hline
\end{tabular}

In Table 1, it can be seen that the results of the reliability coefficients for the total scale range from: 0.898 to 0.901. These results exceed the magnitude of .85, recommended by De Vellis (2012) being considered high (Murphy \& Davidsholder, 1988). Campo-Arias and Oviedo (2008). Reason why, it is not necessary to delete any item, since the index value is high. This proves that it is a positive value, which supports the Oxford inventory (OHI, 2001), to be used as a valid and reliable measuring instrument to assess happiness in university students. 
With the use of binary logistic regression, it can be seen which covariates are the most important to the dependent variable, making use of a statistic called p-value. (statistical measurement, which takes values between 0 and 1), taking a significance level of $5 \%$. According to the results of the binary logistic regression, the following significant covariates were obtained:

- Academic Average

- He is a believer

- Average daily cell phone usage time

Using bivariate analysis, where everything appears summarized in Table 2 Variables (statistical technique that events studies involved two simultaneous variables. For the numerical calculations the distribution Chu-square Bivariate used) that they are not in the equation of the Software SPSS.

Table 2: The variables are not in the equation

\begin{tabular}{|c|c|c|c|c|c|}
\hline & & & Score & GI. & Sig. \\
\hline Step 0 & Variables & Age & .403 & 1 & .526 \\
\hline & & Gender & .124 & 1 & .725 \\
\hline & & Semester & 676 & 1 & 411 \\
\hline & & Economic stratum & .882 & 1 & .348 \\
\hline & & Marital status & 307 & 1 & .580 \\
\hline & & Work & .404 & 1 & .525 \\
\hline & & $\begin{array}{l}\text { The level of your income compared to } \\
\text { your monthly expenses are? }\end{array}$ & .033 & 1 & .855 \\
\hline & & Academic average & 1.360 & 1 & 244 \\
\hline & & Are you a believer? & 8.038 & 1 & .005 \\
\hline & & Who pays for your studies? & .667 & 1 & .414 \\
\hline & & Average daily time using the cellphone & .2851 & 1 & .091 \\
\hline & & Transfer time & .023 & 1 & .879 \\
\hline & & What kind of house do you live in? & .538 & 1 & .463 \\
\hline Global & itistics & & 18.597 & 13 & 136 \\
\hline
\end{tabular}

As Mentioned before, by taking a margin of error of 0.05 (associated with the $\mathrm{p}$ value) with a single degree of freedom, a chi value of 3.8415 is obtained, it can be seen in Table 2, that the only variable that rejects the hypothesis null is the variable "It is a believer" due to its affected chi-squared value 8,038 but $(8,038>3,884)$, so the variable "It is a believer if it influences happiness" can be concluded.

Using the Wald chi-square test for multivariate analysis, knowing that 3.8415 is the chi-square value for a margin of error of 0.05 and a degree of freedom, we can reject the null hypothesis in the variables "Academic average", "He is a believer "and" Average daily time of cell phone use ". Knowing these variables, now it is possible to construct the predictive model, where its general equation is: 


$$
P(Y=1)=\frac{1}{1+e^{\left(-\alpha-\beta_{1} X_{1}-\beta_{2} X_{2}-\beta_{3} X_{3}-\ldots-\beta_{k} X_{k}\right)}}
$$

Taking this information, the variable "It is a believer" to apply the general equation, where the reference category is No, as this way was encoded by the SPSS program. Then the equation would be:

$$
P(F E L I C I D A D=S i)=\frac{1}{1+e^{\left(-0.977-\left(-1.418^{*}\right)\right)}}=0.3915
$$

The average inter-item correlation ranges from .319 to .517 , values that are considered good measures of internal consistency (Merino, Navarro \& García, 2014). From this result it can be interpreted, that with this probability less than 0.50 , a non-believer would be classified as HAPPINESS $=$ No.

In table 2, it can also be seen that there are no gender differences between men and women with respect to satisfaction The results they obtained (Ahn et al., 2012), for Spanish youth are consistent with the above noted, since no differences are appreciated., and in general, they are not statistically significant, Diener et al., (1985), also found in their studies that the gender variable was so insignificant, which corroborates the consistency with the findings previously found.

\section{DISCUSSION AND CONCLUSIONS}

In the present study, the results obtained for Cronbach's alpha coefficient in all cases, presented values ranging from: 0.89 and .90 , these results exceed the magnitude of 0.85 , recommended by DeVellis (2012) being considered high (Murphy \& Davidsholder, 1988). Campo-Arias and Oviedo (2008). Reason why it was not necessary to withdraw any item, since the value of the index is high. The stability of Cronbach's alpha coefficient in the $90 \%$ confidence interval corroborates this result, as suggested by Ledesma (2004), Duhachek and Iacobucci (2004), and Newcombe and Merino (2006). Therefore, the reliability of the twenty-nine questions of the Oxford happiness questionnaire (OHI, 2001) is endorsed, so that it can be used as a valid and reliable measuring instrument to evaluate happiness in university students.

According to the statistical results, (the measurement of the p-value statistic, with a level of significance of 5\%), the following significant covariates were obtained: average daily time of cell phone use, academic average greater than 3.5 and being a believer of a religion What contributes to favor the feeling of being close to God, and this relationship, as with human relationships, positively affects happiness (Argyle, 1999). According to available evidence, it is common in developing countries to find these types of scores in which people are globally satisfied (Diener, 1996), which contributes to scientifically verify the impact of these factors on happiness levels of the university population.

\section{REFERENCES}

1. Alarcón, R. (2009). Desarrollo de una escala factorial para medir la felicidad. Interamerican Journal of Psychology, 40(1), 95102...Recovered from http://pepsic.bvsalud.org/scielo.php?script=sci_arttext\&pid=S003496902006000100010

2. Diener, E Lucas, RE Oishi, S. Avances y preguntas abiertas en la ciencia del bienestar subjetivo Collabra: Psychology Open Access Volume 4, Issue 1, 2018, Article number 16

3. Diener, E. a, b, Seligman, eurodiputado d, Choi, H. b, Oishi, S. b Las personas más felices revisadas (artículo) Perspectivas sobre la ciencia psicológica. Volume 13, Number 2, March 1, 2018, pages 176-184. 
4. Doğan, T. Sapmaz, F. Examen de las propiedades psicométricas de la versión turca del cuestionario de felicidad de Oxford en estudiantes universitarios ISSN: 13095749, DOI: 10.5350 / DAJPN2012250401

5. Easterlin, RA, Angelescu, l. Zweig, JS El impacto del crecimiento económico moderno en las diferencias urbano-rurales en el bienestar subjetivo (Artícule). Volume 39, number 12, december 2011, pages 2187-2198

6. JS Westefeld, SR Furr, "El suicidio y la depresión entre estudiantes.

7. Universitarios", Psicología profesional: investigación y práctica, vol. 18, number. 2, pp. 119, 1987.

8. Heintzelman, SJ, Diener, E. “Bienestar subjetivo, interpretación social y relación próspera” (artículo) University of Virginia, \& University of Utah, Volume 4, Issue 1, 2018, número de artículo 15, Estados Unidos, ISSN: 00926566, DOI: 10.1016 / j.jrp.2018.11.007

9. M Joshanloo Revisiting the empirical distinction between hedonic and eudaimonic aspects of well-being using exploratory structural equation modeling. Journal of Happiness Studies, 2016. Cited by 52 Related articles All 14 versions

10. Natasha Jaques, Sara Taylor, Asaph Azaria, Asma Ghandeharioun, Akane Sano, and Rosalind Picard. Predicting students' happiness from physiology, phone, mobility, and behavioral data, Published online 2015 Dec $7 . \quad$ doi: 10.1109/ACII.2015.7344575

11. Peter Hills*, Michael Argyle the Oxford Happiness Questionnaire: a compact scale for the measurement of psychological wellbeing Received 2 May 2001; received in revised form 11 November 2001; accepted 9 December 2001.

12. Santoso, ds. Kulathunga, ELLA "Examinar la felicidad: hacia una mejor comprensión de la mejora del rendimiento" Tailandia 2016 DOI: $10.1016 / j$. proeng.2016.11.630

13. Veenhoven, R. La felicidad, también conocida como "satisfacción con la vida" y "bienestar subjetivo" Manual de investigación en indicadores sociales y calidad de vida 1 de enero de 2012, páginas 63-77

14. Ziapour, A. ,Khatony, A. Autor de correo electrónico ,Jafari, F. ,Kianipour, N. Correlación de rasgos de personalidad con felicidad entre estudiantes universitarios, ISSN: 2249782X, DOI: 10.7860 / JCDR / 2018 / 31260.11450, Biomedical and Pharmacology Journal Open Access Vol. 9, Número 2, 2016, 

